\title{
PENDEKATAN VECTOR ERROR CORRECTION MODEL UNTUK ANALISIS HUBUNGAN INFLASI, BI RATE DAN KURS DOLAR AMERIKA SERIKAT
}

Vector Error Correction Model Approach to Analysis of the relationship of Inflation, BI Rate and US Dollar

\author{
LEXY JANZEN SINAY \\ Jurusan Matematika Fakultas MIPA Universitas Pattimura \\ Jl. Ir. M. Putuhena, Kampus Unpatti, Poka-Ambon, Maluku \\ E-mail: lj.sinay@staf.unpatti.ac.id
}

\begin{abstract}
ABSTRAK
Pengendalian terhadap tingkat inflasi, BI rate dan nilai tukar dolar Amerika Serikat terhadap rupiah merupakan hal yang paling penting demi terciptanya stabilitas moneter dan perekonomian di Indonesia. Penelitian ini bertujuan untuk memodelkan hubungan antara tingkat inflasi, BI rate, dan nilai tukar USD terhadap IDR, kemudian menganalisis model tersebut, dan memberikan peramalan dan analisis struktural dari model tersebut. Oleh karena itu, metode yang digunakan dalam penelitian ini adalah analisis Vector Error Correction Model yang diterapkan pada data time series dari tingkat inflasi $(\boldsymbol{X})$, BI rate $(\boldsymbol{Y})$, dan nilai tukar USD terhadap IDR $(\boldsymbol{Z})$. Berdasarkan spesifikasi, estimasi dan pemeriksaan model, maka diperoleh model VECM(5) sebagai model terbaik. Hasil analisis model mengatakan bahwa ada hubungan kausalitas jangka panjang dan jangka pendek antara tingkat inflasi dengan BI rate dan nilai tukar USD terhadap IDR. Kemudian, berdasarkan peramalan dan analisis struktural maka dapat disimpulkan bahwa hasil yang diperoleh akurat.
\end{abstract}

Kata kunci : inflasi, BI rate, USD, IDR, time series, Vector Error Correction Model, $\operatorname{VECM}(5)$.

\section{PENDAHULUAN}

Pada tanggal 14 Agustus 1998 Pemerintah Indonesia menerapkan kebijakan sistem nilai tukar mengambang bebas. Kebijakan ini, membawa dampak yang sangat signifikan pada perkembangan perekonomian nasional baik dalam sektor moneter maupun sektor riil. Salah satu dampak yang terjadi adalah depresiasi nilai tukar rupiah terhadap dolar Amerika (USD) menjadi sangat besar. Hal ini mengakibatkan aktivitas bisnis dan ekonomi di Indonesia mengalami ketidakpastian dalam pengambilan keputusan. Oleh karena itu, perlunya kestabilan nilai tukar uang, yaitu dengan menekan nilai tukar USD terhadap nilai tukar rupiah (IDR).

Langkah awal yang perlu dikaji adalah menganalisis faktor-faktor penyebab kenaikan nilai tukar tersebut, baik yang bersifat ekonomi maupun non ekonomi. Pada umumnya faktor non ekonomi yang dianggap sebagai penyebab terjadinya gejolak nilai tukar rupiah terhadap dolar, seperti faktor politik, pertahanan dan keamanan, kebijakan pemerintah dan lain-lain sangat sulit digunakan sebagai acuan pengukuran secara kuantitatif karena tidak dapat diukur. Hal ini berbeda dengan faktor ekonomi, seperti tingkat suku bunga, inflasi, dan lain-lain yang umumnya dapat diukur secara kuantitatif.

Tingkat suku bunga merupakan salah satu faktor penting yang dianggap sangat mempengaruhi nilai tukar mata uang. Di Indonesia tingkat suku bunga diatur oleh pihak Pemerintah melalui Bank Indonesia (BI). Suku bunga Bank Indonesia (BI Rate) adalah suku bunga kebijakan yang mencerminkan sikap atau stance kebijakan moneter yang ditetapkan oleh Bank Indonesia dan diumumkan kepada publik [1]. Dengan demikian, secara sederhana, BI Rate diartikan sebagai suku bunga yang dikeluarkan oleh BI melalui Dewan Gubernur BI pada setiap Rapat Dewan Gubernur bulanan, kemudian BI 
Rate diimplementasikan pada operasi moneter yang dilakukan oleh BI melalui pengelolaan likuiditas (liquidity management) di pasar uang untuk mencapai sasaran operasional kebijakan moneter [1]. Pada umumnya, penetapan BI Rate didasarkan atas analisis ekonomi dan finansial, yaitu mempertimbangkan berbagai faktor ekonomi dan finansial negara Indonesia. Faktor utama yang sering dijadikan sebagai indikasi untuk penetapan BI Rate adalah tingkat inflasi.

Inflasi, secara sederhana, dapat diartikan sebagai peningkatan harga-harga (barang dan jasa) secara umum (menyeluruh) dan terus menerus [1]. Di Indonesia, kebijakan tentang penentuan tingkat inflasi dikeluarkan oleh Badan Pusat Statistik (BPS). Kebijakan ini didasarkan atas Survey Biaya Hidup (SBH), dengan menggunakan Indeks Harga Konsumen (IHK) sebagai indikator untuk menentukan tingkat inflasi [1]. Tingkat inflasi yang tinggi dan tidak stabil cenderung memberi dampak negatif kepada kondisi sosial ekonomi masyarakat yang pada akhirnya mengganggu stabilitas perekonomian, sosial, politik, pertahanan dan kemanan suatu negara. Dengan demikian, kestabilan inflasi sangat penting dan menjadi syarat utama bagi pertumbuhan ekonomi yang positif dan berkesinambungan, yang pada akhirnya memberikan manfaat bagi peningkatan kesejahteraan masyarakat. Untuk itu, pentingnya pengawasan dan pengendalian inflasi oleh berbagai pihak terutama oleh pemerintah.

Di Indonesia, pengendalian inflasi dilakukan oleh pemerintah dengan koordinasi beberapa pihak seperti Bank Indonesia, Kementerian Keuangan, Pemerintah Daerah (Provinsi, Kabupaten/Kota), lembaga keuangan, dan pihak perbankan baik itu BUMN ataupun swasta. Salah satu kebijakan untuk mengendalikan inflasi adalah penentuan BI Rate, kebijakan kestabilan kurs, dan lainlain.

Berdasarkan penjelasan di atas dapat disimpulkan bahwa ada hubungan yang saling mempengaruhi antara kebijakan BI Rate, tingkat inflasi, dan nilai tukar USD terhadap IDR. Ada banyak metode dalam Ekonometrika yang dapat memodelkan hubungan ketiga faktor tersebut dengan kelebihan dan kekurangannya masing-masing. Karena data yang digunakan dalam penelitian ini merupakan data time series (data yang mengandung lag), maka model yang digunakan adalah model regresi time series dengan beberapa peubah, seperti model ARIMAX, model autoregressive distributed lag (ADL), model vector autoregressive (VAR), vector error correction model (VECM), dan lain-lain.

Penelitian ini difokuskan pada model VECM untuk menganalisis hubungan terkointegrasi antara BI Rate, inflasi, dan nilai tukar dolar tanpa memperhatikan stasioneritas data (atau data yang mengandung akar unit). Tujuan dari penelitian ini adalah untuk memodelkan hubungan antara BI rate, inflasi dan nilai tukar USD terhadap IDR; kemudian menganalisis model tersebut berdasarkan struktur model untuk melihat hubungan (pengaruh) masing-masing variabel dalam jangka panjang maupun jangka pendek; serta memberikan peramalan dan analisis struktural dari peramlan tersebut.

\section{TINJAUAN PUSTAKA}

Pada umumnya model ekonometrika time series merupakan model struktural karena didasarkan atas teori ekonomi yang telah ada. Pada tahun 1980 Christopher A. Sims memperkenalkan model VAR sebagai alternatif dalam analisis ekonomi makro. Model VAR merupakan model non struktural karena bersifat ateori. Model VAR memiliki struktur model yang lebih sederhana dengan jumlah variabel yang minimalis dimana semua variabelnya adalah variabel endogen dengan variabel independennya adalah lag. Model VAR didesain untuk variabel stasioner yang tidak mengandung trend [3].

Trend stokastik dalam data mengindikasikan bahwa ada komponen long-run (jangka panjang) dan short-run (jangka pendek) dalam data time series. Penelitian tentang trend stokastik dalam variabel ekonomi terus berkembang, sehingga pada tahun 1981, Granger mengembangkan konsep kointegrasi. Pada tahun 1987, Engle bersama Granger mengembangkan konsep kointegrasi dan koreksi error (error correction). Kemudian, pada tahun 1990, Johansen dan Juselius mengembangkan konsep VECM. VECM menawarkan suatu prosedur kerja yang mudah untuk memisahkan komponen jangka panjang (long-run) dan komponen jangka pendek (short-run) dari proses pembentukan data [5], [6]. Dengan demikian, VECM berbeda dengan VAR dimana VECM dapat digunakan untuk memodelkan data time series yang terkointegrasi dan tidak stasioner. VECM sering disebut sebagai bentuk VAR terestriksi [4].

Berikut ini merupakan kajian analisis VECM secara teoritis:

\section{Uji Akar Unit}

Seperti yang dibahas sebelumnya, pemodelan dengan menggunakan VECM didasarkan atas data time series yang tidak stasioner namun terkointegrasi. Untuk memeriksa stasioneritas data dapat digunakan uji akar unit, dengan statistik uji yang digunakan adalah Augmented Dickey-Fuller (ADF), sebagai berikut:

$$
\Delta Y_{t}=\gamma+\delta t+\rho Y_{t-1}+\sum_{j=1}^{k} \phi_{j} \Delta Y_{t-j}+e_{t}
$$

Dengan $\Delta Y_{t}=Y_{t}-Y_{t-1}$ dan $\rho=a-1$.

Hipotesis

$$
H_{0}: \rho=0 \text { (terdapat akar unit). }
$$

Pada tingkat signifikansi $(1-\alpha) 100 \%, H_{0}$ ditolak jika statistik ADF lebih kecil dari nilai kritis pada saat $\alpha$, atau $p$ value lebih kecil dari nilai signifikansi $\alpha$. Jika $H_{0}$ ditolak maka data stasioner. [2] dan [7]

\section{Uji Kointegrasi Johansen}

Kemudian, untuk uji kointegrasi digunakan uji kointegrasi Johansen sebagai berikut:

Diketahui model $\operatorname{VAR}(p)$ adalah

$$
y_{t}=A_{t} y_{t-1}+\cdots+A_{p} y_{t-p}+B x_{t}+\varepsilon_{t}
$$

dengan $y_{t}$ adalah sebuah vektor dengan $k$ varibel non stasioner I(1), $x_{t}$ adalah sebuah vektor dengan $d$ variabel deterministik, $\varepsilon_{t}$ adalah vektor error. Persamaan $\operatorname{VAR}(p)$ dapat ditulis juga sebagai 
dimana

$$
\Delta y_{t}=\Pi y_{t-1}+\sum_{i=1}^{p-1} \Gamma_{i} \Delta y_{t-i}+B x_{t}+\varepsilon_{t}
$$

$$
\Pi=\sum_{i=1}^{p} A_{i}-I, \quad \Gamma_{i}=-\sum_{j=i+1}^{p} A_{j} .
$$
uji trace:

Untuk pengujian hipotesis dapat digunakan statistik

$$
L R_{t r}(r \mid k)=-T \sum_{i=r+1}^{k} \log \left(1-\lambda_{i}\right)
$$

dan statistik uji nilai Eigen maksimum

untuk $r=0,1, \ldots, k-1$,

$$
\begin{aligned}
L R_{\text {max }}(r \mid r+1) & =-T \log \left(1-\lambda_{r+1}\right) \\
& =L R_{t r}(r \mid k)-L R_{t r}(r+1 \mid k)
\end{aligned}
$$

dengan hipotesis yang digunakan adalah

$$
H_{0} \text { : terdapat } r \text { persamaan kointegrasi. }
$$

Pada tingkat signifikansi $(1-\alpha) 100 \%, H_{0}$ diterima jika statistik uji trace dan nilai Eigen maksimum lebih kecil dari nilai kritis pada saat $\alpha$, atau $p$ value lebih besar dari nilai signifikansi $\alpha$. [2] dan [7]

\section{Uji kecocokan model}

Uji kecocokan model untuk melihat serial korelasi pada residual menggunakan statistik uji Portmanteau sebagai berikut:

$$
Q_{h}=T \sum_{j=1}^{h} \operatorname{tr}\left(\hat{C}_{j}^{\prime} \hat{C}_{0}^{-1} \hat{C}_{j} \hat{C}_{0}^{-1}\right),
$$

atau

$$
Q_{h}^{*}=T^{2} \sum_{j=1}^{h} \frac{1}{T-j} \operatorname{tr}\left(\hat{C}_{j}^{\prime} \hat{C}_{0}^{-1} \hat{C}_{j} \hat{C}_{0}^{-1}\right)
$$

dengan $\hat{C}_{i}=\frac{1}{T} \sum_{t=i+1}^{T} \widehat{\boldsymbol{u}}_{t} \widehat{\boldsymbol{u}}_{t-i}^{\prime}$. Statistik uji ini berdistribusi $\chi_{\left(k^{2}\left(h-n^{*}\right)\right)}$, dengan $n^{*}$ menyatakan jumlah koefisien selain konstanta dalam model $V A R(p)$ yang diestimasi. Hipotesis

$$
H_{0} \text { : tidak ada serial korelasi. }
$$

Pada tingkat signifikansi $(1-\alpha) 100 \%, H_{0}$ diterima jika $p$ value statistik $Q$ untuk setiap lag $h$ lebih besar dari nilai signifikansi $\alpha$. Dengan demikian, tidak ada serial korelasi. [5] dan [6]

\section{Kriteria Informasi}

Pemilihan order lag $p$ dapat menggunakan kriteria informasi berikut:

- Akaike Information Criterion (AIC)

$$
\operatorname{AIC}(p)=\log \operatorname{det}\left(\widehat{\Sigma}_{u}(p)\right)+\frac{2_{p} k^{2}}{T}
$$

- Schwarz Information Criterion (SC)

$$
S C(p)=\log \operatorname{det}\left(\widehat{\Sigma}_{u}(p)\right)+\frac{\log (T) p k^{2}}{T}
$$

Dengan $\hat{\Sigma}_{u}(p)=T^{-1} \sum_{t=1}^{T} \hat{u}_{t} \hat{u}_{t}, \mathrm{~T}$ adalah ukuran sampel dan $k$ adalah jumlah variabel endogen. Nilai lag $p$ dipilih sebagai nilai $p^{*}$ yang meminimumkan kriteria informasi dalam interval $1, \ldots, p_{\max }$ yang diamati. Lag yang optimum didasarkan atas nilai $A I C$ dan $S C$ yang paling kecil. [5] dan [7]

\section{Analisis Kausalitas}

Pada pemodelan VECM, analisis kausalitas bertujuan untuk melihat hubungan jangka panjang (longrun causality) dan hubungan jangka pendek (short-run causality).

Analisis hubungan kausalitas jangka panjang antara variabel independen ke variabel dependen dalam pemodelan VECM dapat dilihat pada koefisien dari bentuk koreksi galat atau error correction term (ECT), yaitu berdasarkan tanda dan hasil uji signifikansi koefisien menggunakan statistik uji $t$ pada metode Ordinary Least Square (OLS).

Sementara itu, untuk analisis kausalitas jangka pendek untuk setiap variabel dapat menggunakan uji kausalitas Granger. Uji kausalitas Granger didasarkan atas statistik uji Wald yang berdistribusi chi square atau uji $F$ sebagai alternatifnya. Hipotesis yang digunakan adalah [5] dan [6]

$H_{0}$ : Tidak ada hubungan kausalitas Granger

\section{Peramalan dan Analisis Struktural}

Secara teoritis, analisis peramalan dan struktural dari VECM memiliki kemiripan dengan analisis peramalan dan analisis struktural dari model VAR. Pada pemodelan VAR analisis tersebut dapat menggunakan analisis impulse response dan dekomposisi variansi [5], [6]. Analisis Impulse Response bertujuan untuk melihat efek (pengaruh) dari setiap variabel (endogen) jika diberikan shock atau impulse (guncangan). Sementara itu, analisis dekomposisi variansi bertujuan untuk memprediksi kontribusi setiap variabel (persentase variansi setiap variabel) yang diakibatkan oleh perubahan variabel tertentu dalam sebuah sistem.

Seperti analisis peramalan pada umumnya, untuk menentukan keakuratan hasil ramalan dari sebuah model dapat menggunakan Mean Absolute Percentage Error $(M A P E)$ :

$$
M A P E=\frac{\sum_{t=1}^{n}\left|\frac{\hat{Y}_{t}-Y_{t}}{Y_{t}}\right|}{n} \times 100 \%
$$

dan Mean Square Error (MSE) :

$$
M S E=\frac{1}{n} \sum_{i=1}^{n}\left(Y_{t}-\hat{Y}_{t}\right)^{2}
$$

dimana $n$ menyatakan jumlah data. Semakin kecil nilai MSE dan MAPE, maka semakin akurat hasil ramalan yang diperoleh. [4]

\section{METODE PENELITIAN}

Pada bagian sebelumnya telah dijabarkan tentang latar belakang dan tujuan dari penelitian ini. Berdasarkan informasi tersebut maka secara ekonomi dapat dirumuskan beberapa hipotesis sebagai berikut:

a. Tingkat inflasi dipengaruhi oleh tingkat suku bunga;

b. Tingkat suku bunga dipengaruhi oleh tingkat inflasi;

c. Tingkat inflasi dipengaruhi oleh kurs (nilai tukar mata uang asing);

d. Tingkat suku bunga dipengaruhi oleh kurs;

e. Kurs dipengruhi oleh tingkat inflasi dan tingkat suku bunga. 
Berdasarkan rumusan hipotesis di atas, maka dapat dibentuk tiga variabel sebagai berikut:

$X$ : Tingkat inflasi;

$Y$ : BI rate;

$Z$ : Nilai tukar dolar Amerika Serikat (USD) terhadap rupiah (IDR).

Dengan demikian, penilitian ini merupakan sebuah studi kasus untuk menganalisis hubungan ketiga variabel tersebut secara makro.

Berdasarkan variabel yang dibentuk, maka data yang digunakan dalam penelitian ini adalah data bulanan pada periode Juli 2005 sampai dengan Desember 2013 dari tingkat inflasi dan BI rate. Sedangkan, data nilai tukar rupiah terhadap dolar yang digunakan merupakan data nilai tengah per akhir bulanan yang dimulai pada tanggal 30 juni 2005 sampai dengan 30 Nopember 2013. Ketiga data ini merupakan data sekunder yang bersumber dari Bank Indonesia yang dipublikasikan secara resmi.

Metode yang digunakan dalam penelitian ini adalah analisis VECM untuk memodelkan ketiga variabel di atas. Prosedur dalam analisis VECM sebagai berikut:

1. Spesifikasi estimasi, dan pemeriksaan model

a. Uji akar unit (pemeriksaan stasineritas)

b. Uji kointegrasi Johansen

c. Estimasi dan Pemeriksaan Model

2. Analisis kausalitas

3. Peramalan dan Analisis struktural

Hasil pengolahan data yang dilakukan pada penelitian ini menggunakan software Eviews 7.

\section{HASIL DAN PEMBAHASAN}

Data Bi Rate (BI), tingkat inflasi yang terjadi di negara Indonesia (INF), dan nilai tengah dari nilai tukar dolar Amerika Serikat (USD) terhadap Rupiah Indonesia (IDR) diberikan pada Gambar 1.

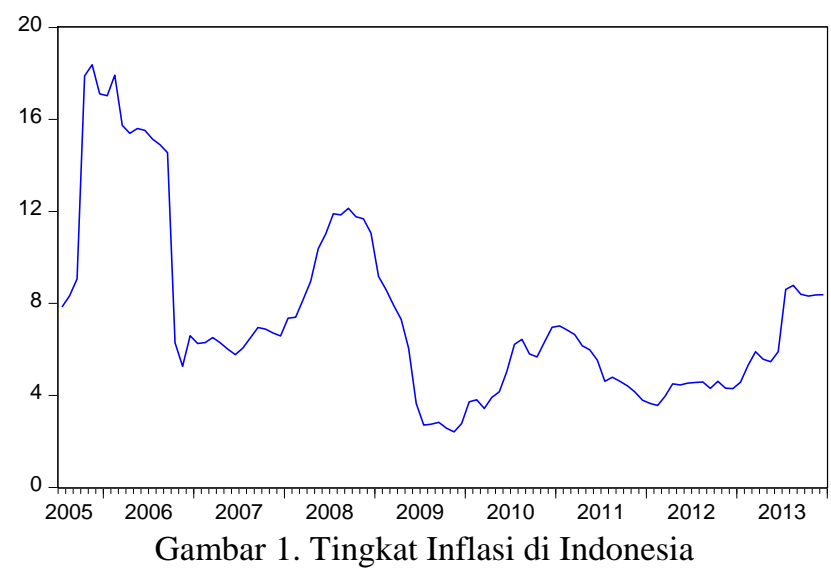

Pada Gambar 1, Gambar 2 dan Gambar 3, dapat dilihat bahwa pola tingkat inflasi, BI rate dan kurs USD memiliki pola yang hampir sama pada beberapa tahun tertentu dalam jangka waktu yang cukup lama. Secara tersirat, hal ini menggambarkan bahwa ada hubungan yang kointegrasi antara ketiga variabel tersebut. Untuk melihat lebih jelas tentang hubungan kointegrasi untuk masing-masing variabel akan digunakan uji kointegrasi
Johansen, namun sebelumnya akan diperiksa stasioneritas dari ketiga data tersebut.
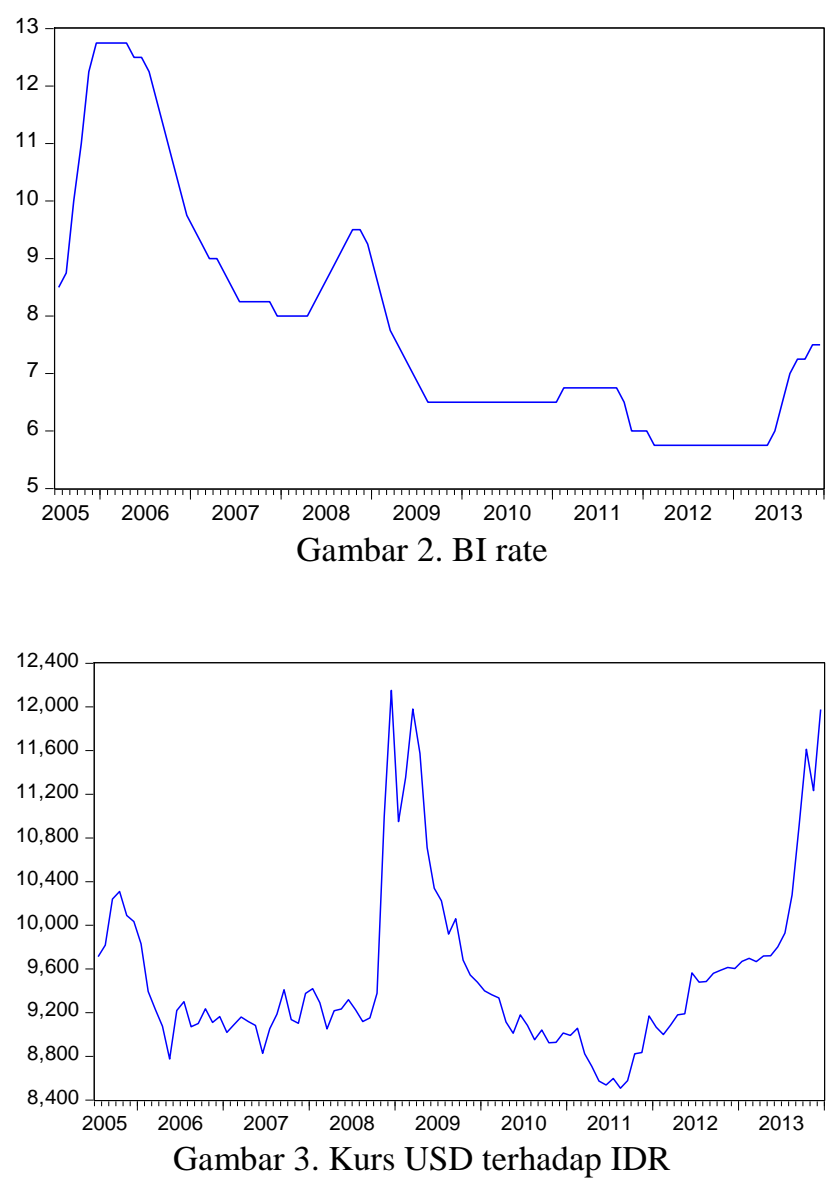

\section{Spesifikasi, Estimasi dan Pemeriksaan Model}

\section{a. Uji Akar Unit (Pemeriksaan Stasioneritas)}

Langkah awal dalam prosedur ini adalah melakukan uji akar unit terhadap ketiga data tersebut. Berdasarkan pengolahan data, diperoleh hasil seperti yang diperlihatkan pada Tabel 1 .

Tabel 1. Uji Akar Unit

\begin{tabular}{|c|c|c|c|c|c|}
\hline \multirow[b]{2}{*}{ Data } & \multirow{2}{*}{$\begin{array}{c}\text { Nilai } \\
\text { Kritis } \\
(\alpha)\end{array}$} & \multicolumn{2}{|c|}{ Level } & \multicolumn{2}{|c|}{ 1st Difference } \\
\hline & & $\begin{array}{l}\text { Stat. } \\
\text { ADF }\end{array}$ & $p$ value & $\begin{array}{l}\text { Stat. } \\
\text { ADF }\end{array}$ & p value \\
\hline $\mathbf{X}$ & & $-2,1747$ & 0,2168 & $-5,6676$ & 0,000 \\
\hline & $5 \%$ & $-2,8906$ & & $-2,8943$ & \\
\hline $\bar{Y}$ & & $-2,1323$ & 0,2327 & $-3,5668$ & 0,0082 \\
\hline & $5 \%$ & $-2,8906$ & & $-2,8906$ & \\
\hline $\bar{Z}$ & & $-1,0268$ & 0,7414 & $-4,3473$ & $\begin{array}{l}\mathbf{0 , 0 0 0 7} \\
\end{array}$ \\
\hline & $5 \%$ & $-2,8903$ & & $-2,8912$ & \\
\hline
\end{tabular}

Sumber: Hasil Pengolahan Data

Berdasarkan Tabel 1 dapat dilihat bahwa data $X, Y$ dan $Z$ merupakan data-data yang mengandung akar unit pada level atau tidak stasioner pada level. Hal ini dapat dilihat pada saat level, $p$ value statistik ADF untuk masing-masing variabel lebih besar dari $\alpha=5 \%$, ini artinya menerima hipotesis $H_{0}$ yaitu terdapat akar unit 
pada data atau data tidak stasioner. Sementara itu, dari hasil diferensi pertama dapat dilihat bahwa $p$ value statistik ADF dari masing-masing variabel lebih kecil dari $\alpha=5 \%$, ini artinya menolak hipotesis $H_{0}$ yaitu data tidak mengandung akar unit atau sudah stasioner. Dengan demikian, variabel $X, Y$ dan $Z$ merupakan variabel non stationer orde pertama.

\section{b. Uji Kointegrasi Johansen}

Hasil uji kointegrasi untuk lag 2 (lag signifikan berdasarkan prosedur $V A R$ ) dari variabel $X, Y$ dan $Z$ dengan menggunakan statistik trace dan statistik nilai Eigen maksimum dapat dilihat pada Tabel 2 dan Tabel 3.

Pada Tabel 2 dapat dilihat bahwa, hasil uji hipotesis dengan menggunakan statitistik trace. untuk hipotesis

$$
H_{0} \text { : Tidak ada persamaan kointegrasi, }
$$

$p$ value adalah 0,0434 lebih kecil dari $\alpha=5 \%$ (Nilai statistik trace 30,3287 lebih besar dari nilai 29,7979 tabelnya pada $\alpha=5 \%$ ). Ini artinya hipotesis $H_{0}$ ditolak. Dengan demikian, dapat disimpulkan bahwa ada persamaan kointegrasi. Untuk itu, dilakukan pemeriksaan untuk hipotesis berikutnya.

Tabel 2. Uji kointegrasi (Trace)

\begin{tabular}{ccccc}
\hline \hline $\begin{array}{c}\text { Hipotesis: } \\
r\end{array}$ & Nilai Eigen & $\begin{array}{c}\text { Trace } \\
\text { Statistic }\end{array}$ & $\begin{array}{c}\text { Nilai kritis } \\
\alpha=5 \%\end{array}$ & $p$ value \\
\hline \hline Tidak ada & 0,184386 & 30,32868 & 29,79707 & 0,0434 \\
1 & 0,084917 & 10,15103 & 15,49471 & 0,2693 \\
2 & 0,013700 & 1,365677 & 3,841466 & 0,2426 \\
\hline \hline
\end{tabular}

Sumber: Hasil Pengolahan Data

Berdasarkan Tabel 2, akan diperiksa hasil uji hipotesis berikut ini:

dan

$$
H_{0} \text { : Ada } 1 \text { persamaan kointegrasi }
$$

$$
H_{0} \text { : Ada } 2 \text { persamaan kointegrasi. }
$$

Pada Tabel 2 dapat dilihat bahwa $p$ value untuk masingmasing hipotesis secara berurutan adalah 0,2693 dan 0,2426 lebih besar dari $\alpha=5 \%$ (statistik trace lebih besar dari nilai kritisnya pada saat $\alpha=5 \%$ untuk masingmasing hipotesis). Ini artinya bahwa menerima $H_{0}$. Dengan demikian, berdasarkan analisis tersebut dapat disimpulkan bahwa hasil uji kointegrasi dengan menggunakan statistik trace mengindikasikan bahwa minimal ada 1 persamaan kointegrasi yang dapat dibentuk.

Tabel 3. Uji kointegrasi (nilai Eigen maksimum)

\begin{tabular}{ccccc}
\hline \hline $\begin{array}{c}\text { Hipotesis: } \\
r\end{array}$ & Nilai Eigen & $\begin{array}{c}\text { Max-Eigen } \\
\text { Statistic }\end{array}$ & $\begin{array}{c}\text { Nilai kritis } \\
\alpha=5 \%\end{array}$ & $p$ value \\
\hline \hline [Tidak ada] & 0,184386 & 20,17765 & 21,13162 & 0,0675 \\
[1] & 0,084917 & 8,785352 & 14,26460 & 0,3045 \\
{$[2]$} & 0,013700 & 1,365677 & 3,841466 & 0,2426 \\
\hline \hline
\end{tabular}

Sumber: Hasil Pengolahan Data
Pada Tabel 3 dapat dilihat bahwa, hasil uji hipotesis dengan menggunakan statitistik nilai Eigen maksimum, yaitu $p$ value statistik trace untuk masing-masing hipotesis

$H_{0}$ : Tidak ada persamaan kointegrasi,

$H_{0}$ : Ada 1 persamaan kointegrasi

dan

$$
H_{0} \text { : Ada } 2 \text { persamaan kointegrasi }
$$

secara berutan adalah 0,$0675 ; 0,3045$; dan 0,2426 lebih besar dari $\alpha=5 \%$ (statistik nilai Eigen maksimum lebih besar dari nilai kritis pada saat $\alpha=5 \%$ untuk masingmasing hipotesis). Ini artinya bahwa masing-masing hipotesis tersebut diterima. Dengan demikian, kesimpulan yang diperoleh dari uji hipotesis berdasarkan nilai Eigen maksimum adalah tidak ada persamaan kointegrasi yang terjadi.

Dari hasil uji kointegrasi dengan dua metode di atas, dapat disimpulkan bahwa minimal ada satu bentuk persamaan kointegrasi artinya bahwa ada satu bentuk error, dengan bentuk persamaan error adalah

$$
\varepsilon_{t}=X_{t}-1,5798 Y_{t}+0,0000401 Z_{t}
$$

Berdasarkan hasil yang diperoleh maka dapat dilakukan estimasi bentuk persamaan VECM.

\section{c. Estimasi dan Pemeriksaan Model}

Prosedur penting dalam mengestimasi persamaan VECM adalah pemilihan lag optimum. Prosedur pemilihan lag optimum dalam VECM dapat menggunakan kriteria informasi, yaitu $A I C$ dan $S C$.

Hasil pengolahan data tentang kedua kriteria informasi tersebut untuk lag 1 sampai dengan lag 8 dapat dilihat pada Tabel 4. Perlu diketahui bahwa penggunaan lag 1 sampai dengan lag 8 dikarenakan prinsip parsimony (kesederhanaan model) dalam pemodelan statistika, karena semakin banyak lag yang digunakan, maka koefisien parameter model semakin banyak.

Tabel 4. Kriteria informasi

\begin{tabular}{ccc}
\hline \hline Lag & AIC & SC \\
\hline \hline 1 & 17,04493 & 17,51386 \\
2 & 16,50059 & $\mathbf{1 7 , 2 0 8 3 5}$ \\
3 & 16,34287 & 17,29245 \\
4 & 16,26006 & 17,45452 \\
5 & $\mathbf{1 6 , 2 2 9 1 7}$ & 17,67162 \\
6 & 16,37575 & 18,06938 \\
7 & 16,39363 & 18,34168 \\
8 & 16,30582 & 18,51163 \\
\hline \hline
\end{tabular}

Sumber: Hasil Pengolahan Data

Pada Tabel 4 dapat dilihat bahwa lag 5 memiliki nilai $A I C$ terkecil, sedangkan lag 2 memiliki nilai $S C$ terkecil. Dengan demikian, lag 2 dan lag 5 akan digunakan untuk proses estimasi parameter VECM. Berdasarkan hasil analisis lag optimum tersebut, maka bentuk persamaan VECM yang diestimasi adalah $\operatorname{VECM}(2)$ dan $\operatorname{VECM}(5)$, masing-masing dengan jumlah persamaan kointegrasi adalah 1. 
Kemudian dilakukan pemeriksaan model untuk memilih model terbaik anatara VECM(2) dan VECM(5). Pemeriksaan model yang dilakukan adalah uji asumsi residual dari kedua model tersebut, yaitu uji serial korelasi residual seperti yang diperlihatkan pada Tabel 5. Pada Tabel 5, dapat dilihat bahwa hasil uji Portmanteau untuk VECM(2) menyatakan bahwa model tersebut mengandung serial korelasi residual pada lag 3, dimana pada lag $3 p$ value dari statistik $Q$ kurang dari taraf signifikansi $\alpha=5 \%$ (artinya menolak $H_{0}$ : tidak ada serial korelasi). Sementara itu, hasil uji Portmanteau untuk $\operatorname{VECM(5)~menyatakan~bahwa~tidak~mengandung~serial~}$ korelasi residual pada setiap lag. Dengan demikian, $\operatorname{VECM(5)~lebih~baik~dibandingkan~} \operatorname{VECM(2)~karena}$ tidak terdapat serial korelasi residual. Ini artinya bahwa $\operatorname{VECM(5)~merupakan~model~terbaik.~}$

Tabel 5. Uji Portmanteau

\begin{tabular}{ccccccc}
\hline \hline & \multicolumn{3}{c}{ VECM(2) } & \multicolumn{3}{c}{ VECM(5) } \\
Lag & Stat. $Q$ & $p$ value & $\mathrm{db}$ & Stat. $Q$ & $p$ value & $\mathrm{db}$ \\
\hline \hline \multirow{2}{*}{1} & 9,607332 & NA* & NA* & 0,464832 & NA* $^{*}$ & NA* \\
2 & 15,22395 & NA* $^{*}$ & NA* & 2,126732 & NA* $^{*}$ & NA* $^{*}$ \\
3 & $\mathbf{2 9 , 0 2 3 6 1}$ & $\mathbf{0 , 0 1 6 0}$ & $\mathbf{1 5}$ & 3,404707 & NA* $^{*}$ & NA* $^{*}$ \\
4 & 33,80128 & 0,0883 & 24 & 7,532918 & NA* $^{*}$ & NA* $^{*}$ \\
5 & 44,05873 & 0,0945 & 33 & 10,97131 & NA* $^{*}$ & NA* $^{*}$ \\
6 & 49,15562 & 0,2083 & 42 & 14,15259 & 0,5140 & 15 \\
7 & 55,85669 & 0,2974 & 51 & 25,64869 & 0,3712 & 24 \\
8 & 64,40410 & 0,3252 & 60 & 30,64600 & 0,5848 & 33 \\
9 & 70,76791 & 0,4184 & 69 & 35,98643 & 0,7313 & 42 \\
10 & 83,23205 & 0,3217 & 78 & 45,31610 & 0,6979 & 51 \\
11 & 93,24688 & 0,3040 & 87 & 47,14269 & 0,8864 & 60 \\
12 & 100,5661 & 0,3548 & 96 & 53,96726 & 0,9080 & 69 \\
\hline \hline
\end{tabular}

Sumber: Hasil Pengolahan Data adalah

Dengan demikian, bentuk persamaaan $\operatorname{VECM(5)}$

$$
\begin{aligned}
\Delta X_{t}= & 0,314\left(X_{t-1}-1,63 Y_{t-1}+0,0005 Z_{t-1}+0,59\right) \\
& +0,264 \Delta X_{t-1}-0,099 \Delta X_{t-2}+0,052 \Delta X_{t-3} \\
& +0,015 \Delta X_{t-4}-0,067 \Delta X_{t-5}+2,49 \Delta Y_{t-1} \\
& +0,938 \Delta Y_{t-2}+0,764 \Delta Y_{t-3}-1,617 \Delta Y_{t-4} \\
& +1,197 \Delta Y_{t-5}+7,84 \times 10^{-5} \Delta Z_{t-1} \\
& +0,00014 \Delta Z_{t-2}+0,00035 \Delta Z_{t-3} \\
& +9,85 \times 10^{-05} \Delta Z_{t-4}+0,001 \Delta Z_{t-5} \\
& +0,0959
\end{aligned}
$$

$$
\begin{array}{rl}
\Delta Y_{t}=0 & 011\left(X_{t-1}-1,63 Y_{t-1}+0,0005 Z_{t-1}+0,59\right) \\
& +0,027 \Delta X_{t-1}+0,0297 \Delta X_{t-2}-0,0155 \Delta X_{t-3} \\
& +0,0315 \Delta X_{t-4}+0,0041 \Delta X_{t-5}+0,659 \Delta Y_{t-1} \\
& -0,083 \Delta Y_{t-2}+0,023 \Delta Y_{t-3}-0,072 \Delta Y_{t-4} \\
& -0,047 \Delta Y_{t-5}-5,799 \times 10^{-5} \Delta Z_{t-1} \\
& -5,797 \times 10^{-5} \Delta Z_{t-2}-6,577 \times 10^{-5} \Delta Z_{t-3} \\
& -4,17 \times 10^{-5} \Delta Z_{t-4}+3,45 \times 10^{-5} \Delta Z_{t-5} \\
& -0,019
\end{array}
$$

$$
\begin{aligned}
\Delta Z_{t}=- & 9,282\left(X_{t-1}-1,63 Y_{t-1}+0,0005 Z_{t-1}+0,59\right) \\
& +0,883 \Delta X_{t-1}-15,39 \Delta X_{t-2}-50,33 \Delta X_{t-3} \\
& -50,55 \Delta X_{t-4}+7,978 \Delta X_{t-5}+335,14 \Delta Y_{t-1} \\
& +248,9 \Delta Y_{t-2}+291,3 \Delta Y_{t-3}-230,9 \Delta Y_{t-4} \\
& +89,787 \Delta Y_{t-5}+0,173 D \Delta Z_{t-1}-0,228 \Delta Z_{t-2} \\
& +0,329 \Delta Z_{t-3}+0,122 \Delta Z_{t-4}+0,081 \Delta Z_{t-5} \\
& +48,8496
\end{aligned}
$$

\section{Analisis Kausalitas Granger}

Berdasarkan bentuk persamaan (1) model VECM(5) di atas, diketahui bahwa variabel independen persamaan tersebut adalah tingkat inflasi (diferensi pertama dari $X$ ). Pada persamaan tersebut dapat dilihat bahwa koefisien persamaan kointegrasi adalah -0,314. Dengan kata lain, koefisien ECT bertanda negatif. Berdasarkan hasil pengolahan data, diperoleh bahwa $p$ value untuk statistik $t$ adalah 0,0002 kurang dari taraf signifikansi $\alpha=5 \%$, yang berarti bahwa koefisien tersebut merupakan koefisien yang signifikan. Dengan demikian, koefisien ECT pada persamaan (1) merupakan koefisien yang signifikan dan bertanda negatif. Ini berarti bahwa, terdapat hubungan kausalitas jangka panjang (long-run causality) dari BI rate dan nilai tukar USD terhadap tingkat inflasi.

Tabel 6. Uji Kausalitas Granger: Variabel Dependen $\Delta X_{t}$

\begin{tabular}{cccc}
\hline \hline Excluded & Chi-sq & $\mathrm{db}$ & $p$ value \\
\hline \hline$\Delta Y_{t}$ & 25,48137 & 5 & 0,0001 \\
$\Delta Z_{t}$ & 9,415045 & 5 & 0,0936 \\
\hline \hline All & 31,38931 & 10 & 0,0005 \\
\hline \hline
\end{tabular}

Sumber: Hasil Pengolahan Data

Untuk melihat hubungan kausalitas jangka pendek (short-run causality) pada persamaan (1) dapat menggunakan Uji kausalitas Granger seperti yang diperlihatkan pada Tabel 6. Pada Tabel 6 dapat dilihat bahwa $p$ value statistik uji Wald untuk variabel $\Delta Y_{t}$ adalah 0,0001 lebih kecil dari taraf signifikan $\alpha=5 \%$. Ini berarti bahwa, menolak hipotesis $H_{0}$ : tidak ada hubungan kausalitas antara variabel. Dengan demikian, terdapat hubungan kausalitas jangka pendek antara BI rate terhadap tingkat inflasi. Sementara itu, untuk variabel $\Delta Z_{t}$ memiliki $p$ value adalah 0,0936 lebih dari taraf signifikan $\alpha=5 \%$. Ini berarti bahwa menerima hipotesis $H_{0}$ pada taraf signifikansi $\alpha=5 \%$ atau tidak ada hubungan kausalitas jangka pendek antara nilai tukar USD terhadap tingkat inflasi. Namun, jika dilihat secara keseluruhan pada persamaan (1), maka terdapat hubungan kausalitas jangka pendek dari BI rate dan USD terhadap tingkat inflasi. Hal ini dikarenakan oleh $p$ value $=$ 
0,0005 lebih kecil dari taraf signifikan $\alpha=5 \%$, yang artinya bahwa menolak hipotesis $H_{0}$.

Berikut, berdasarkan bentuk persamaan (2) dengan variabel independen adalah BI rate (diferensi pertama dari $Y$ ), maka dapat dilihat bahwa koefisien persamaan kointegrasi adalah 0,011. Berdasarkan hasil pengolahan data, diperoleh bahwa $p$ value untuk statistik $t$ adalah 0,3118 lebih dari taraf signifikansi $\alpha=5 \%$, yang berarti bahwa koefisien tersebut tidak signifikan. Dengan demikian, koefisien ECT bertanda positif dan tidak signifikan. Ini berarti bahwa, tidak terdapat hubungan kausalitas jangka panjang (long-run causality) dari tingkat inflasi dan nilai tukar USD terhadap BI rate.

Berdasarkan hasil uji kausalitas Granger pada Tabel 7, maka analisis hubungan kausalitas jangka pendek (short-run causality) pada persamaan (2) sebagai berikut: $p$ value statistik uji Wald untuk variabel $\Delta X_{t}$ adalah 0,0065 lebih kecil dari taraf signifikan $\alpha=5 \%$. Ini berarti bahwa, menolak hipotesis $H_{0}$ yang berarti terdapat hubungan kausalitas jangka pendek antara tingkat inflasi terhadap BI rate. Sementara itu, $p$ value variabel $\Delta Z_{t}$ memiliki adalah 0,2181 lebih dari taraf signifikan $\alpha=5 \%$, yang berarti bahwa menerima $H_{0}$ atau tidak ada hubungan kausalitas jangka pendek antara nilai tukar USD terhadap BI rate. Namun, secara keseluruhan pada persamaan (2) terdapat hubungan kausalitas jangka pendek dari tingkat inflasi dan nilai tukar USD terhadap BI rate. Hal ini dikarenakan oleh $p$ value $=0,004$ lebih kecil dari taraf signifikan $\alpha=5 \%$, yang artinya bahwa menolak hipotesis $H_{0}$.

Tabel 7. Uji Kausalitas Granger: Variabel Dependen $\Delta Y_{t}$

\begin{tabular}{cccc}
\hline \hline Excluded & Chi-sq & $\mathrm{db}$ & $p$ value \\
\hline \hline$\Delta X_{t}$ & 16,11923 & 5 & 0,0065 \\
$\Delta Z_{t}$ & 7,034041 & 5 & 0,2181 \\
\hline \hline All & 25,81654 & 10 & 0,0040 \\
\hline \hline
\end{tabular}

Sumber: Hasil Pengolahan Data

Kemudian, bentuk persamaan (3) dengan variabel independen adalah BI rate (diferensi pertama dari $Z$ ), dapat dilihat bahwa koefisien persamaan kointegrasi adalah -9,282. Berdasarkan hasil pengolahan data, diperoleh bahwa $p$ value untuk statistik $t$ adalah 0,7431 kurang dari taraf signifikansi $\alpha=5 \%$, yang berarti bahwa koefisien tersebut tidak signifikan. Dengan demikian, koefisien ECT bertanda negatif dan tidak signifikan. Ini berarti bahwa, tidak terdapat hubungan kausalitas jangka panjang (long-run causality) dari tingkat inflasi dan BI rate terhadap nilai tukar USD.
Kemudian, dengan menggunakan menggunakan Uji kausalitas Granger pada Tabel 8, maka dapat dianalisis hubungan kausalitas jangka pendek (short-run causality) pada persamaan (3) sebagai berikut: $p$ value statistik uji Wald untuk variabel $\Delta X_{t}$ adalah 0,518 lebih besar dari taraf signifikan $\alpha=5 \%$. Ini berarti bahwa, menerima hipotesis $H_{0}$, yaitu tidak terdapat hubungan kausalitas jangka pendek antara tingkat inflasi terhadap nilai tukar USD. Sementara itu, untuk variabel $\Delta Y_{t}$ memiliki $p$ value adalah 0,278 lebih besar dari taraf signifikan $\alpha=5 \%$, artinya bahwa menerima hipotesis $H_{0}$, dengan kata lain tidak ada hubungan kausalitas jangka pendek antara variabel BI rate terhadap nilai tukar USD. Secara keseluruhan pada persamaan (3), dapat dilihat bahwa tidak terdapat hubungan kausalitas jangka pendek dari tingkat inflasi dan BI rate terhadap nilai tukar USD. Hal ini dikarenakan oleh $p$ value $=0,6277$ lebih besar dari taraf signifikan $\alpha=5 \%$, yang artinya bahwa menerima hipotesis $H_{0}$.

Tabel 8. Uji Kausalitas Granger: Variabel Dependen $\Delta Z_{t}$

\begin{tabular}{cccc}
\hline \hline Excluded & Chi-sq & $\mathrm{db}$ & $p$ value \\
\hline \hline$\Delta X_{t}$ & 4,221556 & 5 & 0,5180 \\
$\Delta Y_{t}$ & 6,300783 & 5 & 0,2780 \\
\hline \hline All & 8,011534 & 10 & 0,6277 \\
\hline \hline
\end{tabular}

Sumber: Hasil Pengolahan Data

\section{Peramalan dan Analisis Struktural}

Bagian ini akan membahas tentang peramalan dan analisis struktur peramalan dari model VECM(5). Sebelum, membahas tentang hasil peramalan (lihat Tabel 12) akan dibahas terlebih dahulu tentang analisis struktural yang mencakup analisis Impulse-Response dan dekomposisi variansi.

\section{a. Analisis Impulse - Response}
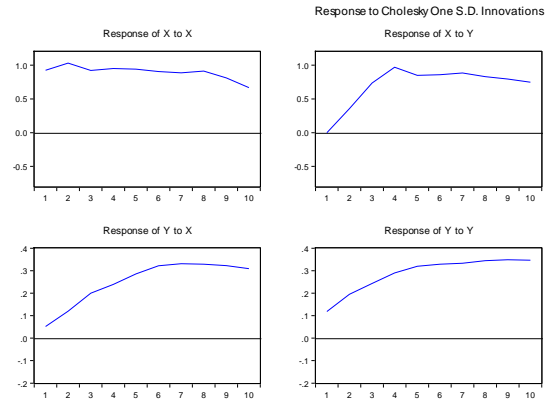

Response of $Y$ to $Y$

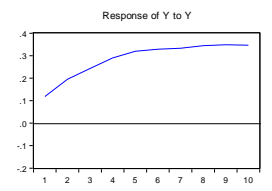

Response of $z$ to $Y$
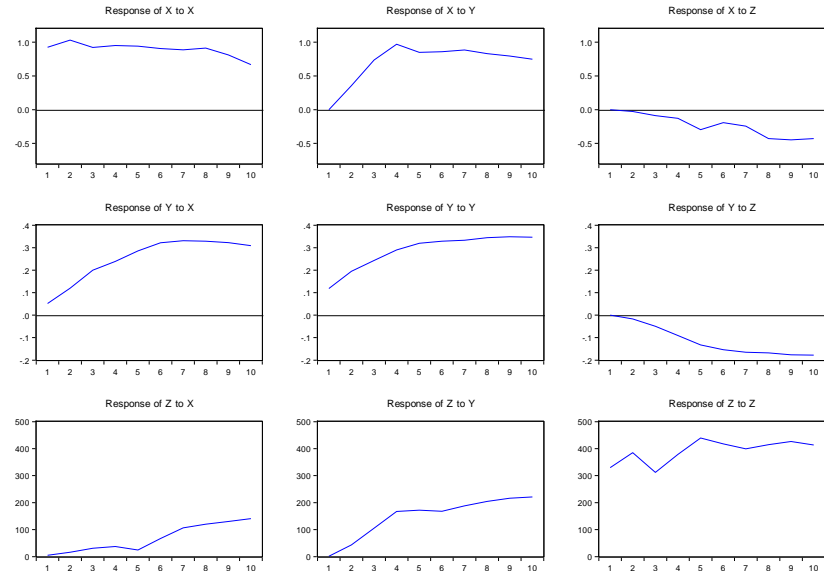

Response of $Y$ to $Z$
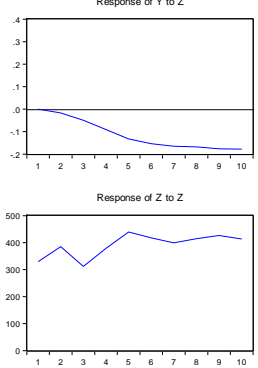

Gambar 4. Analisis Impulse - Response 
Analisis impulse-response dapat menggunakan fungsi impulse-response (IRF). Hasil plot dari IRF dapat dilihat pada Gambar 4. Pada Gambar 4 dapat dilihat bahwa ada 9 plot IRF untuk 10 kuartal ke depan, yang mana menjelaskan secara visual tanggapan (response) suatu variabel yang timbul karena adanya guncangan (shock/impulse) sebesar 1 standar deviasi baik dari dirinya sendiri ataupun variabel lain.

Berdasarkan Gambar 4, analisis IRF dari tingkat inflasi untuk 10 kuartal ke depan sebagai berikut:

- Respons tingkat inflasi terhadap guncangan dari dirinya sendiri pada kuartal 1 cukup besar, yaitu 0,92. Meskipun pada kuartal 2 sempat mengalami kenaikan menjadi 1,03 , namun hingga kuartal 10 respons terhadap guncangan (dari dirinya sendiri) mengalami penurunan. Ini berarti bahwa setelah kuartal 2 reaksi tingkat inflasi terhadap guncangan dari dirinya sendiri cenderung menjadi lemah.

- Respons tingkat inflasi terhadap guncangan dari BI rate pada kuartal 1 sampai dengan 4 terus meningkat, namun pada kuartal 5 sampai dengan kuartal 10 mengalami penurunan. Ini berarti bahwa pada kuartal 5 sampai dengan 10 reaksi yang diberikan oleh tingkat inflasi terhadap guncangan BI rate cenderung menjadi lemah.

- Respons tingkat inflasi terhadap guncangan dari nilai tukar USD cenderung bernilai negatif. Ini artinya bahwa jika terjadi guncangan sebesar 1 standar deviasi dari nilai tukar USD maka tingkat inflasi akan bereaksi negatif terhadap nilai tukar USD.

Kemudian, dari Gambar 4, analisis IRF dari BI rate untuk 10 kuartal ke depan sebagai berikut:

- Respons BI rate terhadap guncangan dari tingkat inflasi pada kuartal 1 sampai dengan kuartal 7 mengalami peningkatan. Kemudian, pada kuartal 8 sampai dengan 10 mengalami penurunan, artinya bahwa setelah kuartal 7 reaksi tingkat inflasi terhadap guncangan dari tingkat inflasi cenderung menjadi lemah.

- Respons BI rate terhadap guncangan dari dalam dirinya sendiri cenderung menguat pada kuartal 1 sampai dengan kuartal 9 karena mengalami peningkatan. Kemudian, pada kuartal 10 mengalami penurunan.

- Sama seperti tingkat inflasi, Respons BI rate terhadap guncangan dari nilai tukar USD cenderung bernilai negatif. Ini artinya bahwa jika terjadi guncangan sebesar 1 standar deviasi dari nilai tukar USD maka BI rate akan bereaksi negatif terhadap nilai tukar USD

Berdasarkan Gambar 4, analisis IRF dari BI rate untuk 10 kuartal ke depan sebagai berikut:

- Respons nilai tukar USD terhadap guncangan dari tingkat inflasi pada kuartal 1 sampai dengan kuartal 10 mengalami peningkatan yang sangat signifikan. Ini berarti bahwa guncangan sebesar 1 standar deviasi dari tingkat inflasi mengakibatkan kenaikan yang sangat signifikan terhadap nilai tukar USD.

- Respons nilai tukar USD terhadap guncangan dari BI rate pada kuartal 1 sampai dengan kuartal 10 mengalami peningkatan yang sangat signifikan. Ini berarti bahwa guncangan sebesar 1 standar deviasi dari BI rate mengakibatkan kenaikan yang sangat signifikan terhadap nilai tukar USD.

- Respons nilai tukar USD terhadap guncangan dari dalam dirinya sendiri pada kuartal 1 sampai dengan kuartal 10 mengalami fluktuasi untuk setiap kuartal secara berurutan.

\section{b. Dekomposisi Variansi}

Analisis dekomposisi variansi sering disebut sebagai analisis forecast error decomposition variance (FEDV). Hasil analisis FEDV untuk 10 kuartal dari masing-masing variabel dapat dilihat pada Tabel 9, Tabel 10, dan Tabel 11.

Tabel 9. Dekomposisi Variansi: Variabel $X$

\begin{tabular}{ccccc}
\hline \hline Periode & S.E. & $X$ & $Y$ & $Z$ \\
\hline \hline 1 & 0,923738 & 100,0000 & 0,000000 & 0,000000 \\
2 & 1,430307 & 93,75786 & 6,206312 & 0,035826 \\
3 & 1,856583 & 80,38549 & 19,36614 & 0,248372 \\
4 & 2,303307 & 69,24007 & 30,29115 & 0,468773 \\
5 & 2,646314 & 65,13373 & 33,25540 & 1,610868 \\
6 & 2,932219 & 62,58508 & 35,66979 & 1,745128 \\
7 & 3,198492 & 60,29931 & 37,65002 & 2,050675 \\
8 & 3,455090 & 58,65580 & 38,04786 & 3,296343 \\
9 & 3,664425 & 57,06196 & 38,52114 & 4,416896 \\
10 & 3,823323 & 55,46613 & 39,21758 & 5,316292 \\
\hline \hline
\end{tabular}

Sumber: Hasil Pengolahan Data

Tabel 9 merupakan rangkuman hasil analisis FEDV untuk tingkat inflasi dari guncangan yang diberikan oleh masing-masing variabel termasuk dirinya sendiri. Analisis FEDV pada Tabel 9 menyatakan bahwa dalam jangka pendek, yaitu kuartal 3: guncangan terhadap dirinya sendiri mengakibatkan $80,39 \%$ fluktuasi dalam tingkat inflasi, dan guncangan terhadap BI rate mengakibatkan $19,37 \%$ fluktuasi dalam tingkat inflasi, serta guncangan terhadap nilai tukar USD mengakibatkan $0,25 \%$ fluktuasi dalam tingkat inflasi. Di lain pihak dalam jangka panjang, yaitu pada quartal 10: guncangan terhadap dirinya sendiri mengakibatkan semakin lemah fluktuasi dalam tingkat inflasi, sedangkan guncangan terhadap BI rate dan nilai tukar USD mengakibatkan fluktuasi semakin meningkat dalam tingkat inflasi. Secara umum, fluktuasi yang diakibatkan oleh guncangan nilai tukar USD dalam tingkat inflasi sangat kecil.

Kemudian, analisis FEDV untuk BI rate (lihat Tabel 10) menyatakan bahwa dalam jangka pendek, yaitu kuartal 3: guncangan terhadap dirinya sendiri mengakibatkan $65,05 \%$ fluktuasi dalam BI rate, dan guncangan terhadap tingkat inflasi mengakibatkan $33,34 \%$ fluktuasi dalam BI rate, serta guncangan terhadap nilai tukar USD mengakibatkan $1,6 \%$ fluktuasi dalam BI rate. Di lain pihak dalam jangka panjang, yaitu pada quartal 10: guncangan terhadap dirinya sendiri mengakibatkan semakin lemah fluktuasi dalam BI rate, sedangkan guncangan terhadap tingkat inflai dan nilai tukar USD mengakibatkan fluktuasi semakin meningkat dalam BI rate. Secara umum, fluktuasi yang diakibatkan 
oleh guncangan nilai tukar USD dalam BI rate sangat kecil.

Tabel 10. Dekomposisi Variansi: Variabel $Y$

\begin{tabular}{ccccc}
\hline \hline Periode & S.E. & $X$ & $Y$ & $Z$ \\
\hline \hline 1 & 0,129489 & 15,89009 & 84,10991 & 0,000000 \\
2 & 0,263355 & 24,55518 & 75,01779 & 0,427027 \\
3 & 0,413055 & 33,34726 & 65,05035 & 1,602390 \\
4 & 0,565776 & 35,60401 & 60,97999 & 3,415995 \\
5 & 0,721861 & 37,49763 & 57,03236 & 5,470008 \\
6 & 0,869624 & 39,49582 & 53,60463 & 6,899542 \\
7 & 1,001796 & 40,67585 & 51,42611 & 7,898037 \\
8 & 1,121838 & 41,01592 & 50,44462 & 8,539466 \\
9 & 1,230898 & 40,92709 & 49,92568 & 9,147236 \\
10 & 1,327414 & 40,60364 & 49,73674 & 9,659619 \\
\hline \hline
\end{tabular}

Sumber: Hasil Pengolahan Data

Kemudian, berdasarkan Tabel 11, analisis FEDV untuk nilai tukar USD menyatakan bahwa dalam jangka pendek, yaitu kuartal 3: guncangan terhadap dirinya sendiri mengakibatkan 96,15\% fluktuasi dalam nilai tukar USD, dan guncangan terhadap tingkat inflasi mengakibatkan $0.34 \%$ fluktuasi dalam nilai tukar USD, serta guncangan terhadap BI rate mengakibatkan 3,51\% fluktuasi dalam BI rate. Di lain pihak dalam jangka panjang, yaitu pada quartal 10: guncangan terhadap dirinya sendiri mengakibatkan semakin lemah fluktuasi dalam nilai tukar USD, sedangkan guncangan terhadap tingkat inflasi dan BI rate mengakibatkan fluktuasi semakin meningkat dalam nilai tukar USD. Secara umum, fluktuasi yang diakibatkan oleh guncangan tingkat inflasi dalam nilai tukar USD sangat kecil.

Tabel 11. Dekomposisi Variansi: Variabel $Z$

\begin{tabular}{ccccc}
\hline \hline Periode & S.E. & $X$ & $Y$ & $Z$ \\
\hline \hline 1 & 329,5605 & 0,023750 & 0,002306 & 99,97394 \\
2 & 508,9282 & 0,111969 & 0,729639 & 99,15839 \\
3 & 606,8796 & 0,336047 & 3,512566 & 96,15139 \\
4 & 735,7820 & 0,484846 & 7,577222 & 91,93793 \\
5 & 874,3194 & 0,421859 & 9,232363 & 90,34578 \\
6 & 985,7046 & 0,797017 & 10,16773 & 89,03525 \\
7 & 1085,121 & 1,617891 & 11,38355 & 86,99855 \\
8 & 1185,630 & 2,378605 & 12,51501 & 85,10639 \\
9 & 1284,964 & 3,048226 & 13,48344 & 83,46833 \\
10 & 1375,145 & 3,706177 & 14,36396 & 81,92986 \\
\hline \hline
\end{tabular}

Sumber: Hasil Pengolahan Data

\section{c. Hasil Ramalan}

Hasil ramalan dengan menggunakan $\operatorname{VECM}(5)$ untuk 10 periode (bulan) ke depan dapat dilihat pada Tabel 12. Hasil yang diperoleh pada Tabel 12 merupakan hasil ramalan dari tingkat inflasi dan BI Rate pada periode Januari 2014 sampai dengan Oktober 2014, sedangkan hasil ramalan dari nilai tukar USD adalah ramalan untuk periode Desember 2013 sampai dengan September 2014 (nilai tukar USD per akhir bulan). Selain itu, pada Tabel 12 terdapat data aktual untuk 10 bulan dari tingkat inflasi,
BI rate dan nilai tukar USD. Periode untuk masingmasing variabel pada data aktual sama dengan periode data hasil ramalan, yaitu tingkat inflasi dan BI rate pada periode yang sama (Januari 2014 sampai dengan Oktober 2014), sedangkan nilai tukar USD terhadap IDR merupakan data per akhir bulan yang dimulai dari Desember 2013 sampai dengan September 2014.

Tabel 12. Hasil Ramalan dan Data Aktual

\begin{tabular}{ccccccc}
\hline \hline \multirow{2}{*}{ Periode } & \multicolumn{2}{c}{ Inflasi $(X)$} & \multicolumn{2}{c}{ BI Rate $(Y)$} & \multicolumn{2}{c}{ USD $(Z)$} \\
& Act. & Fore. & Act. & Fore. & Act. & Fore. \\
\hline \hline \multirow{2}{*}{1} & 8.22 & 9.12 & 7.50 & 7.52 & $12,189.00$ & $11,996.40$ \\
2 & 7.75 & 9.29 & 7.50 & 7.48 & $12,226.00$ & $12,169.81$ \\
3 & 7.32 & 8.46 & 7.50 & 7.47 & $11,634.00$ & $12,066.77$ \\
4 & 7.25 & 7.27 & 7.50 & 7.38 & $11,404.00$ & $12,147.79$ \\
5 & 7.32 & 6.69 & 7.50 & 7.26 & $11,532.00$ & $12,313.61$ \\
6 & 6.70 & 6.40 & 7.50 & 7.17 & $11,611.00$ & $12,383.05$ \\
7 & 4.53 & 5.77 & 7.50 & 7.07 & $11,969.00$ & $12,442.38$ \\
8 & 3.99 & 5.11 & 7.50 & 6.93 & $11,591.00$ & $12,546.30$ \\
9 & 4.53 & 4.65 & 7.50 & 6.78 & $11,717.00$ & $12,609.07$ \\
10 & 4.83 & 4.18 & 7.75 & 6.64 & $12,212.00$ & $12,629.03$ \\
\hline \hline
\end{tabular}

Act. $=$ Actual $($ Data Aktual $) ;$ Fore $=$ Forecast $($ Hasil Ramalan $)$ Sumber: Hasil Pengolahan Data

Berdasarkan Tabel 12, maka dapat diperoleh nilai $M S E$ dan MAPE dari masing-masing variabel seperti yang diperlihatkan pada Tabel 13. Pada Tabel 13 dapat dilihat bahwa $M S E$ dan $M A P E$ terkecil adalah variabel $Y$ atau BI rate. Ini artinya bahwa peramalan dengan menggunakan model $\operatorname{VECM}(5)$ lebih akurat jika diterapkan pada BI Rate.

Tabel 13. Keakuratan hasil Ramalan

\begin{tabular}{lccc}
\hline \hline & Inflasi $(X)$ & BI Rate $(Y)$ & USD $(Z)$ \\
\hline \hline$M S E$ & 0,82 & 0,24 & $409,413,05$ \\
$M A P E$ & $13,12 \%$ & $4,73 \%$ & $4,89 \%$ \\
\hline \hline
\end{tabular}

Sumber: Hasil Pengolahan Data

\section{KESIMPULAN}

Berdasarkan hasil dan pembahasan, maka dapat disimpulkan bahwa:

1. Berdasarkan spesifikasi model (analisis lag optimum) dan pemeriksaan model (uji serial korelasi residual), maka diperoleh model terbaik untuk data tingkat inflasi, Bi rate dan nilai tukar USD terhadap IDR adalah $\operatorname{VECM}(5)$.

2. Berdasarkan $\operatorname{VECM}(5)$, diperoleh hasil analisis kausalitas sebagai berikut:

a. Terdapat hubungan kausalitas jangka pendek maupun jangka panjang antara tingkat inflasi sebagai variabel dependen dengan BI rate dan nilai tukar USD.

b. Tidak terdapat hubungan kausalitas jangka pendek antara BI rate sebagai variabel dependen dengan 
tingkat inflasi dan nilai tukar USD, namun sebaliknya terdapat hubungan jangka panjang antara BI rate sebagai variabel dependen dengan tingkat inflasi dan nilai tukar USD

c. Tidak terdapat hubungan kausalitas jangka pendek maupun jangka panjang antara nilai tukar USD sebagai variabel dependen dengan tingkat inflasi dan $\mathrm{BI}$ rate.

3. Berdasarkan analisis struktural dari $\operatorname{VECM(5),~dapat~}$ disimpulkan bahwa:

a. Respon dari masing-masing variabel terhadap guncangan yang berasal dari dirinya sendiri cukup signifikan, karena terjadi fluktuasi.

b. Respon dari tingkat inflasi dan BI rate terhadap guncangan dari nilai tukar USD tidak signifikan. Sebaliknya respon nilai tukar USD terhadap guncangan dari tingkat inflasi sangat signifikan.

c. Secara umum, untuk analisis ke depan baik itu dalam jangka panjang maupun jangka pendek, tingkat inflasi dan BI rate saling mempengaruhi secara signifikan, dan kedua variabel tersebut secara signifikan mempengaruhi nilai tukar USD terhadap IDR. Sementara itu, nilai tukar USD terhadap IDR memiliki pengaruh yang kurang signifikan terhadap tingkat inflasi dan BI rate.

4. Hasil ramalan yang diperoleh dengan menggunakan $\operatorname{VECM(5)~cukup~akurat,~terutama~untuk~meramalkan~}$ $\mathrm{BI}$ rate. Hal ini dapat dilihat dari nilai $M S E$ dan $M A P E$ dari BI rate.

Perlu diketahui bahwa BI rate merupakan kebijakan yang dikeluarkan oleh Pemerintah yang disesuaikan dengan keadaan ekonomi yang terjadi di Indonesia. Berbeda dengan BI rate dan nilai tukar USD terhadap IDR. Kedua hal ini merupakan kejadian-kejadian ekonomi yang diakibatkan oleh berbagai faktor baik itu kebijakan yang dikeluarkan oleh Pemerintah atau bukan. Untuk itu, disarankan bahwa perlu adanya kajian-kajian secara sistematis untuk menjaga kestabilan tingkat inflasi dan nilai tukar USD terhadap IDR.

\section{DAFTAR PUSTAKA}

[1] Bank Indonesia, 2014, www.bi.go.id.

[2] Eviews, 2009, EViews 7 User's Guide II, Quantitative Micro Software, Irvine CA.

[3] Gujarati, D., 2004, Basic Econometrics, 4th Edition, Mc. Graw Hill, New York.

[4] Juanda, B \& Junaidi, 2012, Ekonometrika Deret Waktu, IPB Press, Bogor.

[5] Lutkepohl, H., 2006, New Introduction to Multiple Time Series Analysis, Springer-Verlag, Berlin.

[6] Lutkepohl, H., 2011, Vector Autoregressive Models. EUI Working Paper ECO 2011/30, Department of Economics, European University Institute, Florence.

[7] Rosadi, D., 2012, Ekonometrika dan Analisis Runtun Waktu Terapan dengan Eviews, Penerbit Andi Offset, Yogyakarta. 